Dhaka Univ. J. Biol. Sci. 24(1): 53-57, 2015 (January)

\title{
NUTRIENT LOSSES OF AGRICULTURAL LAND DUE TO BRICK MANUFACTURING IN THE CENTRAL REGION OF BANGLADESH
}

\author{
M.K. Rahman*, M. EunuCH, G.M. Fazlul Haque, H.R. Khan \\ AND A.J.M. AbDur Rouf ${ }^{1}$ \\ Department of Soil, Water and Environment, University of Dhaka, \\ Dhaka-1000, Bangladesh
}

Key words: Agricultural land, Brick manufacturing, Nutrient loss

\begin{abstract}
Nutrient losses due to brick production were evaluated at 50 Upazilas in nine districts of the central region of Bangladesh. The average land area occupied by a brick kiln was 0.59 ha. Water- extractable $\mathrm{N}, \mathrm{P}, \mathrm{K}$ and $\mathrm{S}$, and total $\mathrm{N}, \mathrm{P}, \mathrm{K}$ and $S$ decreased by $67,60,62,53,67,67,87$ and $33 \%$ in burnt bricks compared to unburnt one, respectively. Permanent loss of huge quantity of plant nutrients is occurring due to brick manufacturing every year in Bangladesh.
\end{abstract}

\section{Introduction}

Soil is a fragile resource that can be lost or degraded that it is no longer useful to support crops. These adverse effects can be especially pronounced for soils abused by the several anthropogenic activities including brick manufacturing(1). Eight major conflicting land uses have been identified in Bangladesh, agriculture vs brickfields is one of them (2). Brick making is associated with enormous heat evolution, pollution and loss of fertility by which soil becomes unable to grow significant amounts of plants. Brick burning including fire wood, coal etc. also emits oxides of nitrogen, methane, carbon dioxide and other toxic gases to the atmosphere. About $7 \%$ of the total land area of Bangladesh is under degradation ${ }^{(3)}$. Brick kilns continuously engulfing good quality agricultural lands all over the country. As a result, plant nutrients are depleting continuously from agricultural lands because of brick manufacturing. Brick kilns alter the physico-chemical properties, and plant nutrient status of the soils permanently. In many areas, bricks are made from top soils and this becomes a major cause of depletion of fertile soil. A scanty information is available in the literature on nutrient losses due to brick production in Bangladesh $^{(4)}$.

So, the objective of this study was to assess the depletion of fertile agricultural land and nutrient losses viz. nitrogen, phosphorus, potassium and sulfur in burnt bricks compared to unburnt one produced at 50 Upazilas of nine districts in Bangladesh.

*Author for correspondence: <krahman.swe@gmail.com>. ${ }^{1}$ Ministry of Science and Information \& Communication Technology, Bangladesh Secretariat, Dhaka 1000, Bangladesh 


\section{Materials and Methods}

Unburnt and burnt bricks were collected from 50 Upazilas at the rate of one brick kiln per Upazila of nine districts in Dhaka division. Brick kilns were surveyed and data regarding the land area occupied by a brick kiln was recorded. Samples of unburnt and burnt bricks were collected, air-dried, crushed and passed through $2 \mathrm{~mm}$ mesh sieves and kept in plastic bottles for chemical analysis. Air-dried samples were analyzed in triplicate and calculation was done on dry weight basis. Water-extractable $\mathrm{N}$ was determined following micro-Kjeldahl's distillation method ${ }^{(5)}$. Available P was extracted with $0.5 \mathrm{M} \mathrm{NaHCO}_{3}$ as recommended by Olsen et al.(6) and determined with a spectrophotometer. Water- extractable potassium and sulfur were measured by flame photometer and spectrophotometer, respectively. Total nitrogen was determined by micro-Kjeldahl's distillation method(5). Total phosphorus, potassium and sulfur contents were determined by digestion with a mixture of concentrated $\mathrm{HCl} / \mathrm{HNO}_{3}(1: 3)$ as described by Schlichting et al.(7). Total phosphorus was determined by the yellow color method(5), total potassium by flame photometer and total sulfur was measured by spectrophotometer after developing turbidity with $\mathrm{BaCl}_{2}$ using Tween-80, respectively. Mean and standard deviation were determined following statistical packages in Office 2000 program.

\section{Results and Discussion}

The average land area occupied by a brick kiln was 0.59 ha. Water-extractable nitrogen, phosphorus, potassium and sulfur reflect the availability of these essential plant nutrients. The highest concentration of nitrogen $(47.6 \mathrm{mg} / \mathrm{kg})$ in unburnt bricks was found at Dhaka and lowest $(23 \mathrm{mg} / \mathrm{kg}$ ) at Madaripur with a mean value of $35.24 \mathrm{mg} / \mathrm{kg}$, while the highest and lowest concentrations were observed to be 15.25 and $10 \mathrm{mg} / \mathrm{kg}$ in burnt bricks at Rajbari, and Munshiganj and Gazipur, respectively and the mean value was $11.65 \mathrm{mg} / \mathrm{kg}$. The highest concentration of phosphorus $(4.06 \mathrm{mg} / \mathrm{kg})$ was noticed in unburnt bricks at Rajbari as compared to the lowest value $(1.7 \mathrm{mg} / \mathrm{kg})$ at Tangail with a mean of $2.7 \mathrm{mg} / \mathrm{kg}$, while in the burnt bricks the highest and lowest concentrations were 1.55 and $0.72 \mathrm{mg} / \mathrm{kg}$ at Rajbari and Tangail, respectively. Highest potassium concentration in unburnt bricks (225.4 mg/kg) was observed at Munshiganj and lowest $(97 \mathrm{mg} / \mathrm{kg}$ ) was recorded at Faridpur with a mean of $146.86 \mathrm{mg} / \mathrm{kg}$, whereas the highest potassium concentration $(90.8 \mathrm{mg} / \mathrm{kg})$ was recorded at Munshiganj and lowest concentration (42.14 $\mathrm{mg} / \mathrm{kg}$ ) was observed at Faridpur with a mean of $56.22 \mathrm{mg} / \mathrm{kg}$ in the burnt bricks. Highest concentration of sulfur $(27.54 \mathrm{mg} / \mathrm{kg})$ was recorded in unburnt bricks at Munshiganj and lowest concentration $(8.06 \mathrm{mg} / \mathrm{kg}$ ) was observed at Shariatpur with a mean value of $15.36 \mathrm{mg} / \mathrm{kg}$, whereas the highest sulfur concentration $(12.54 \mathrm{mg} / \mathrm{kg})$ was found at Munshiganj and lowest $(4.33 \mathrm{mg} / \mathrm{kg}$ ) at Gazipur with a mean of $7.21 \mathrm{mg} / \mathrm{kg}$ in

burnt bricks was recorded. The mean values of total $\mathrm{N}, \mathrm{P}, \mathrm{K}$ and $\mathrm{S}$ contents in unburnt 
bricks were 0.06, 0.03, 1.47 and $0.03 \%$ (Table 1 ) and in burnt bricks were $0.02,0.01,0.19$ and $0.02 \%$, respectively.

Table 1. Average values of plant nutrients content in unburnt and burnt bricks of nine districts in Bangladesh.

\begin{tabular}{|c|c|c|c|c|c|c|c|c|c|}
\hline \multirow{2}{*}{$\begin{array}{l}\text { Locations } \\
\text { (Districts) }\end{array}$} & \multirow[b]{2}{*}{$\begin{array}{l}\text { Type of } \\
\text { bricks }\end{array}$} & \multicolumn{2}{|l|}{$\mathbf{N}$} & \multicolumn{2}{|l|}{$\mathbf{P}$} & \multicolumn{2}{|l|}{$\mathbf{K}$} & \multicolumn{2}{|l|}{$S$} \\
\hline & & $\begin{array}{l}\text { Water } \\
\text { extractable } \\
(\mathrm{mg} / \mathrm{kg})\end{array}$ & $\begin{array}{c}\text { Total } \\
(\%)\end{array}$ & $\begin{array}{l}\text { Water } \\
\text { extractable } \\
(\mathrm{mg} / \mathrm{kg})\end{array}$ & $\begin{array}{l}\text { Total } \\
(\%)\end{array}$ & $\begin{array}{l}\text { Water } \\
\text { extractable } \\
(\mathrm{mg} / \mathrm{kg})\end{array}$ & $\begin{array}{l}\text { Total } \\
(\%)\end{array}$ & $\begin{array}{l}\text { Water } \\
\text { extractable } \\
(\mathrm{mg} / \mathrm{kg})\end{array}$ & $\begin{array}{l}\text { Total } \\
(\%)\end{array}$ \\
\hline Munshiganj & Unburnt & 39.40 & 0.06 & 3.21 & 0.03 & 225.40 & 1.53 & 27.24 & 0.06 \\
\hline Dhaka & & 47.60 & 0.07 & 2.90 & 0.03 & 214.80 & 1.69 & 22.76 & 0.05 \\
\hline Faridpur & & 32.57 & 0.05 & 2.59 & 0.03 & 97.00 & 1.69 & 11.65 & 0.03 \\
\hline Shariatpur & & 31.20 & 0.05 & 2.60 & 0.03 & 122.40 & 1.61 & 8.06 & 0.02 \\
\hline Gopalganj & & 39.60 & 0.06 & 1.85 & 0.02 & 112.60 & 1.37 & 12.37 & 0.03 \\
\hline Gazipur & & 29.83 & 0.05 & 1.98 & 0.02 & 135.17 & 1.01 & 10.01 & 0.02 \\
\hline Tangail & & 38.50 & 0.06 & 1.70 & 0.02 & 136.80 & 0.93 & 12.46 & 0.03 \\
\hline Rajbari & & 35.50 & 0.06 & 4.06 & 0.04 & 132.25 & 1.65 & 10.08 & 0.02 \\
\hline Madaripur & & 23.00 & 0.04 & 3.42 & 0.03 & 145.33 & 1.76 & 23.60 & 0.05 \\
\hline Mean & & 35.24 & 0.06 & 2.70 & 0.03 & 146.86 & 1.47 & 15.36 & 0.03 \\
\hline Sd & & 7.09 & 0.01 & 0.78 & 0.01 & 44.01 & 0.31 & 7.11 & 0.02 \\
\hline Munshiganj & Burnt & 10.00 & 0.02 & 1.24 & 0.01 & 90.80 & 0.13 & 12.54 & 0.03 \\
\hline Dhaka & & 13.20 & 0.03 & 1.24 & 0.01 & 66.20 & 0.15 & 10.04 & 0.02 \\
\hline Faridpur & & 10.71 & 0.02 & 1.26 & 0.01 & 42.14 & 0.19 & 5.12 & 0.01 \\
\hline Shariatpur & & 11.00 & 0.02 & 1.14 & 0.01 & 45.60 & 0.17 & 5.02 & 0.01 \\
\hline Gopalganj & & 11.00 & 0.02 & 0.83 & 0.01 & 45.20 & 0.16 & 5.56 & 0.01 \\
\hline Gazipur & & 10.00 & 0.02 & 0.78 & 0.01 & 44.67 & 0.10 & 4.33 & 0.01 \\
\hline Tangail & & 12.00 & 0.02 & 0.72 & 0.01 & 52.30 & 0.11 & 4.93 & 0.01 \\
\hline Rajbari & & 15.25 & 0.03 & 1.55 & 0.02 & 63.75 & 0.26 & 5.38 & 0.01 \\
\hline Madaripur & & 11.67 & 0.02 & 1.03 & 0.01 & 55.33 & 0.41 & 11.95 & 0.03 \\
\hline Mean & & 11.65 & 0.02 & 1.09 & 0.01 & 56.22 & 0.19 & 7.21 & 0.02 \\
\hline $\mathrm{Sd}$ & & 1.68 & 0.00 & 0.27 & 0.00 & 15.55 & 0.10 & 3.31 & 0.01 \\
\hline DOAC(\%) & & 67 & 67 & 60 & 67 & 62 & 87 & 53 & 33 \\
\hline
\end{tabular}

DOAC $=$ Decreased over average content in unbunt soil.

The values of water-extractable N, P, K and S, and total N, P, K and S varied among the brick kilns considerably possibly due to variation in topography, soil types, landscapes, slopes, physico-chemical properties, fire severity, temperature, fire frequency and clay mineralogy of the soils, fertilizer application to crops, brick manufacturing processes, cropping pattern and management practices. Water-soluble nitrogen, phosphorus, potassium and sulfur, and total content of nitrogen, phosphorus, potassium and sulfur decreased by $67,60,62,53,67,67,87$ and $33 \%$ in burnt bricks, respectively (Table 1). Nitrogen and sulfur might be lost in the gaseous form to the atmosphere. Any high-temperature burning or heating of organic materials, may evolve some of the nitrogen and sulfur as oxides, which then oxidize to nitric and sulfuric acid(8). Hot- 
burning forest wildfires convert a great deal of nitrogen and sulfur, and some phosphorus, to gaseous forms in which they are lost from the site ${ }^{(9)}$. In burnt bricks, the decrease of phosphorus is in agreement with the findings of Romanya et al.(10) The decrease of potassium content in burnt bricks coincides with the findings of Tiedman and Anderson ${ }^{(11)}$, and Raison et al. ${ }^{(12)}$ but contrast to the findings of Pantami et al. (13). The present experiment is increasing awareness about the situation of plant nutrient losses and environmental pollution created by burning of bricks.

The present experiment revealed that brick manufacturing through burning causes huge losses of fertile agricultural lands as well as nutrients in the central region of Bangladesh.

\section{Acknowledgements}

Research fund was provided by the Ministry of Science and Information \& Communication Technology, Government of the People's Republic of Bangladesh. Authors are grateful to the Department of Soil, Water and Environment, University of Dhaka, DC Offices, Custom Offices and owners of the brick kilns for their co-operation during this research work.

\section{References}

1. Manahan SE 2009. Fundamentals of Environmental Chemistry. $3^{\text {rd }}$ edn., CRC Press, Taylor Sand Francis Group. Boca Raton, FL, USA. pp. 1233.

2. Brandon C 1998. Environmental degradation and agricultural growth. In: Bangladesh Agriculture in the 21st Century. University Press Limited, Dhaka. pp. 109-117.

3. Eswaran H, SM Varmani and LD Spivey Jr 1993. Sustainable agriculture in developing countries: Constrains, challenges and choices. In: Technologies for Sustainable Agriculture in the Tropics. Ragland J and Lal R (eds), pp. 7- 24. ASA Sp. Publ. 56, Madison, WI.

4. Rahman MK, HR Khan and AJMA Rouf 2010. Influence of brick kilns on agricultural land depletion in the southwestern region of Bangladesh. Bangladesh J. Sci. Res. 23(2): 137- 144.

5. Jackson ML 1958. Soil Chemical Analysis. Prentice-Hall Inc., Englewood Cliffs, NJ. pp. 498.

6. Olsen SR, CV Cole, FS Watanabe and LA Dean 1954. Estimation of available phosphorus in soils by extraction with sodium bicarbonate. United States Department of Agriculture, Circular 939, Washington District of Columbia , USA. p. 19.

7. Schlichting E, HP Blume and K Stahr 1995. Bodenkundliches Parktikum. No. 81. Blackwell Wissenchafts-Verlag, Berlin. pp. 295.

8. Gardiner DT and RW Miller 2008. Soils in Our Environment. 11 $1^{\text {th }}$ edn., Pearson Education, Inc., Upper Saddle River, New Jersey, USA. pp. 600.

9. Brady NC and RR Weil 2008. The Nature and Properties of Soils. $14^{\text {th }}$ edn. Pearson Education, Inc., Upper Saddle River, New Jersey 07458. pp. 975. 
10. Romanya J, PK Khanna and RJ Raison 1994. Effects of slash burning on soil phosphorus fractions and sorption and desorption of phosphorus. Forest Ecology and Management 65 (2-3): 89- 103.

11. Tiedman AR and E Anderson 1980. Combustion losses of sulfur and forest foliage and litter. Forest Sci. 33: 216-223.

12. Raison RJ, PK Khanna and PV Woods 1985. Mechanisms of element transfer to the atmosphere during vegetation fires. Can. J. Forest Res. 15: 132-140.

13. Pantami SA, N Voncir, GA Babaji and S Mustapha 2010. Effect of burning on soil chemical properties in the dry sub-humid savanna zone of Nigeria. Researcher 2(7): 78-83.

(Manuscript received on 21 October, 2014; .;revised on 1 December, 2014) 